Article

\title{
The Press as a Resource for Promoting Sustainability Competencies in Teacher Training: The Case of SDG 7
}

\author{
Raquel Chuliá-Jordán *(D), Amparo Vilches Peña (1) and María Calero Llinares (1)
}

Citation: Chuliá-Jordán, R.; Vilches Peña, A.; Calero Llinares, M. The Press as a Resource for Promoting Sustainability Competencies in Teacher Training: The Case of SDG 7. Sustainability 2022, 14, 857. https:// doi.org/10.3390/su14020857

Academic Editors: Monica Herrero and Olga Mayoral

Received: 12 December 2021

Accepted: 8 January 2022

Published: 12 January 2022

Publisher's Note: MDPI stays neutral with regard to jurisdictional claims in published maps and institutional affiliations.

Copyright: (C) 2022 by the authors. Licensee MDPI, Basel, Switzerland. This article is an open access article distributed under the terms and conditions of the Creative Commons Attribution (CC BY) license (https:// creativecommons.org/licenses/by/ $4.0 /)$.
Department of Experimental and Social Sciences Education, Faculty of Teacher Training, University of Valencia, 46022 Valencia, Spain; amparo.vilches@uv.es (A.V.P.); maria.calero@uv.es (M.C.L.)

* Correspondence: raquel.chulia@uv.es

\begin{abstract}
Given the seriousness of the socio-environmental situation we are facing, this study aims to contribute to the involvement of teachers in education for sustainability through the use of non-formal education, particularly the press. The main objectives of the present study are to analyse the use of the press in science education, as well as the design, implementation and evaluation of tools aimed at teachers and trainee researchers in order to encourage and promote attention to the Sustainable Development Goals (SDGs) and more specifically SDG 7 (clean and affordable energy for all) in science education. The proposals are carried out using a constructivist methodology in sessions structured in small collaborative groups. The initial results show that attention to the press is still insufficient, but that, nevertheless, the strategies designed contribute to raising awareness of the importance of SDG 7 and to the classroom treatment of the energy issue among the participants in the study who attend a Master's degree program in secondary education teacher training (specialising in physics and chemistry) and a Master's degree program in research in specific didactics (specialising in experimental sciences).
\end{abstract}

Keywords: Sustainable Development Goals (SDGs); Education for Sustainability (ESD); science; technology; society and environment education (STSE); energy issues; non-formal education; teacher training

\section{Introduction}

We live in a context characterised by the close interrelation between a series of serious problems, such as pollution and degradation of ecosystems, climate change, resource depletion, inequalities and extreme poverty, among others. This planetary emergency [1] is linked to the pursuit of particular, short-term interests, creating a set of problems that are mutually reinforcing and even endangering the continuity of the human species [2-7].

This has led to numerous calls for attention from both specialists and international organisations $[1,4,6,8-10]$ to change irresponsible attitudes and practices and has pointed to education and the media as key pillars to achieve citizen involvement. To this end, among others, the so-called Earth Summits were held (Rio de Janeiro, 1992; Johannesburg, 2002; Rio de Janeiro, 2012) to promote the intervention of all educators linked to both formal and non-formal education (including the media) and to help educate citizens about the pressing planetary situation so that they can participate in decision-making and in the actions required based on a correct perception and awareness of the world's problems [4,6,11-14]. Again, along these lines, between 2005 and 2014, the United Nations promoted the so-called Decade of Education for Sustainable Development [15,16]. More recently, on 25th September 2015, at a summit held in New York, the United Nations (UN) General Assembly adopted the 2030 Agenda for Sustainable Development [17]. This agenda proposes 17 closely interconnected Sustainable Development Goals (SDGs) and 169 specific targets to be achieved by 2030 . However, this great opportunity for all countries and their citizens to get involved in solving socio-environmental problems and contribute to improving life on the planet may be underestimated, according to a report by The Global 
Carbon Project published in the prestigious journal Nature [18] and presented at the 24th Conference of the Parties (COP24) in Katowice (Poland, 2018).

It is, therefore, necessary for teachers to be trained in Education for Sustainability and, more specifically, in the SDGs, which, due to their universal nature, will contribute to the acquisition of a holistic view of the set of problems and challenges we face. Teachers need to acquire the competencies to put them into practice, engaging in the necessary actions to ensure their successful incorporation into the curriculum [19-23]. This incorporation will contribute to sustainability science by addressing complex challenges (inter- and transdisciplinary in a broad temporal and spatial perspective) involving very diverse but closely linked problems, none of which can be solved in isolation, such as the serious situation generated by COVID-19, which has been linked to the way in which human beings relate to nature. Therefore, this health crisis is part of a global crisis that must be seen as a whole [24-27].

\subsection{The Press as a Resource in Science Teacher Training. Focus on the Sustainable Development Goals}

(SDGs). Theoretical Framework

In order to involve citizens in the necessary actions, a fundamental role is attributed to non-formal science education ("out-of-school" education) due to its ability to encourage interest and participation [28-30]. In this sense, the importance given to non-formal science education in educational research has increased significantly in recent decades $[26,28,30-37]$. The publication of the Second International Handbook of Science Education [30] is of outstanding importance, as it devotes eight chapters to out-of-school learning.

As a sign of the importance given, in particular, to the use of the press in formal education, we can mention the publication of monographic issues on this topic in science education journals (Journal in Research in Science Teaching; Aster; International Journal of Science Education; Alambique; Culture and Education, etc.).

Likewise, the influence of the media in raising public awareness of socio-environmental issues and sustainable behaviour has been widely recognised for decades [38-50]. Their integration in the science classroom has also been studied by different authors, whose research shows the possibilities they offer [51,52] and even focuses on the use of digital press releases, highlighting their potential as a resource to promote scientific literacy $[53,54]$.

Most of these studies refer to the potential role of the press as a resource for scientific literacy in secondary education but do not consider the important role that this resource can play, at the same time, in teacher education. Thus, as a complement of previous research, the central aim of this study is to develop proposals for the better and greater use of the press in teacher training based on the interdependence between formal education and the media, as well as the need to establish links between these two cultures to ensure a practical and operational symbiosis, "each in its specificity and without priority" [55]. Within this framework, considering the press as a motivating resource that allows citizens to analyse their environment and to be an active and dynamic part of changing their reality [56], this study aims to contribute to answering the following questions:

- Does science education research pay attention to the use of the press?

- Is it possible to involve teachers in addressing the SDGs in science lessons using the press as a resource?

- In particular, given the importance of the study of energy in the science curriculum, could the preparation and implementation of didactic interventions using the press for the study of SDG 7 (focusing on sustainable energy) help to engage teachers and teachers-in-training on the SDGs and ESD?

\subsection{Hypotheses Guiding the Research}

In order to begin to answer these questions, this paper focuses on the analysis of the use of non-formal education in science classes. Specifically, we present and analyse proposals for the use of the press in teacher training as an instrument that is particularly 
suitable for presenting socio-environmental issues as a whole, i.e., in an integrated way, in particular, to work on the universal SDGs, thus contributing to the necessary citizen education for the transition to sustainability [23,26,57].

In this perspective, the initial conjectures that focus this research are based on the extensive literature on the role of non-formal education (press, science and technology museums, documentaries, etc.) in citizen education for sustainability [20,58-61]. Therefore, we believe that:

Insufficient attention has been paid to the use of the press as an educational resource in science education research.

The design and implementation of media-based interventions in teacher training can contribute to the knowledge and involvement in the achievement of the SDGs, in particular SDG 7, focusing on sustainable energy use.

As didactic research has shown, the introduction of Education for Sustainable Development (ESD) in education requires changes at the structural, curricular and training levels [23,62]. Modifying learning spaces so that they are participatory and favour the construction of knowledge is essential in order to overcome the unidirectional conception of knowledge and encourage the principles and culture of sustainability to be present $[63,64]$. However, at present, as we have pointed out, there are still shortcomings with regards to ESD in the objectives of scientific subjects $[13,65,66]$, which shows the need for educational actions that transform our conceptions, customs, actions and perspectives, in order to enable collective progress towards a more sustainable and just society [7].

In this sense, it is necessary to promote a process of curricular sustainability that favours the development of competencies in sustainability and the training of people who know how to critically analyse the interrelations between environmental, social and economic aspects so that, in their decisions, they seek the most sustainable and socially responsible options [27]. In 2005, the Conference of Deans of Spanish Universities (CRUE, in its Spanish original) approved a document called the Guidelines for Curricular Sustainability, which was revised and reaffirmed in 2012 [67]. The document stated that all degree programs need to incorporate teaching methods and contents that will provide future decision-makers with technical competencies and ethical competencies to address the complex set of needs of our planet and the people who inhabit it [21]. Four sustainability competencies were proposed in this document (Table 1). This general framework of four sustainability competencies was contextualized to different disciplines participating in the Spanish project EDINSOST (education and social innovation for sustainability) [68-70]. For university degrees in education, six units of competence were defined, as shown in Table 1. It is a map that aims to be a compilation of the SCs proposed by experts [71,72], together with those suggested in the United Nations Economic Commission for Europe (UNECE) reports on Education for Sustainable Development (ESD) [73-75] and those proposed by the UNESCO [10] and by the Conference of Deans of Spanish Universities [67].

Therefore, both nationally and internationally, competencies for sustainability have been the subject of numerous contributions and reviews [10,19,20,61,67-77].

In parallel, due to their universal nature, the SDGs can be an excellent tool to contribute to the incorporation of ESD into the teaching and learning process. While not forgetting the close links between all of them, in this study, we will focus on two Sustainable Development Goals that should be very present in science subjects: SDG 7, which aims to "ensure access to affordable, safe, sustainable and modern energy for all", and SDG 13, which addresses issues related to "taking urgent action to combat climate change and its impacts". All this is within the framework of SDG 4, which aims to "ensure inclusive, equitable and quality education and promote lifelong learning opportunities for all". Target 4.7 specifically points to the need to "ensure that all learners acquire the knowledge and skills necessary to promote sustainable development, including through education for sustainable development and sustainable lifestyles, human rights, gender equality, promotion of a culture of peace and 
non-violence, global citizenship and appreciation of cultural diversity and the contribution of culture to sustainable development".

Table 1. Sustainability competencies map for university degrees in education. Source: [67-70].

\begin{tabular}{|c|c|}
\hline $\begin{array}{l}\text { Sustainability Competencies } \\
\text { [67] }\end{array}$ & $\begin{array}{l}\text { Unit of Competency } \\
\text { [68-70] }\end{array}$ \\
\hline $\begin{array}{l}\text { SC1 } \\
\text { Competence in the critical contextualisation of knowledge } \\
\text { through establishing links between social, economic and } \\
\text { environmental issues on a local and/or global level }\end{array}$ & $\begin{array}{l}\text { 1.1 Understanding how natural, social and economic systems } \\
\text { function and the mutual interrelations between them, as well as } \\
\text { the problems related to them, both locally and globally } \\
\text { 1.2 Owning critical reflection and creativity, taking advantage of } \\
\text { the different opportunities presented (ICT, strategic plans, } \\
\text { regulations, etc.) in planning a sustainable future }\end{array}$ \\
\hline $\begin{array}{l}\text { SC2 } \\
\text { Competence in the sustainable use of resources and in the } \\
\text { prevention of negative impacts on the natural and social } \\
\text { environments }\end{array}$ & $\begin{array}{l}2.1 \text { Designing and developing actions, making decisions that } \\
\text { take into account the environmental economic, social, cultural } \\
\text { and educational impacts to improve sustainability }\end{array}$ \\
\hline $\begin{array}{l}\text { SC3 } \\
\begin{array}{c}\text { Competence to participate in community processes that } \\
\text { promote sustainability }\end{array}\end{array}$ & $\begin{array}{l}\text { 3.1 Promoting and collaborating in socio-educational actions as } \\
\text { part of a cooperative community, including the participation of } \\
\text { different stakeholders and co-responsibility with sustainability }\end{array}$ \\
\hline $\begin{array}{l}\text { SC4 } \\
\text { Competence to apply ethical principles related to sustainability } \\
\text { values in personal and professional behaviour }\end{array}$ & $\begin{array}{l}\text { 4.1 Taking actions, respecting and valuing diversity (biological, } \\
\text { social and cultural) and committing itself to the improvement of } \\
\text { sustainability } \\
\begin{array}{c}\text { 4.2 Promoting educational values oriented towards the training } \\
\text { of a responsible, active and democratic citizenship }\end{array}\end{array}$ \\
\hline
\end{tabular}

The holistic vision of the SDGs, in which energy and environmental problems are contemplated together with social problems, all of which are linked, marks the line to be followed to advance in the transition towards a sustainable society, which should be driven by the education system itself. The aim is for personal and collective quality of life to be interconnected with a "healthy planetary life" [78]. To this end, it is urgent to bridge the gap between research and the analysis and promotion of policies that contribute to the fulfilment of the 2030 Agenda [79].

This work aims to improve science education by enriching it through the implementation of Education for Sustainability through the press, encouraging critical reflection and learning together to build a sustainable present and future through action [11]. In this sense, the role, use and analysis of press articles or news items as sources of data collection is important in this collaborative research perspective, which is oriented towards the practice itself. It is characterised by its spiral process, which includes identifying the importance of the problem, formulating questions, issuing hypotheses, developing designs for testing them, analysing the results, reconsidering the problem if necessary, and implementing and evaluating the results of informed educational measures. All of the above justifies the need for greater involvement of the education system to promote awareness of the SDGs [23] and thus contribute to building a sustainable planet for present and future generations [78].

\section{Materials and Methods}

Research in the field of science education supports the idea of the importance of the use of the press in the classroom, with a wide range of possibilities for actions that contribute to the scientific literacy of citizens $[26,80]$.

To this end, we propose designs that attempt to demonstrate the ability to use the press to contribute, through ESD, to knowledge and involvement in the transition to sustainability and, above all, in the achievement of the SDGs, focusing on SDG 7. The aim is to show, with some examples of intervention, that these uses are possible and that they can be a useful and motivating tool for students and teachers in training. This will make it 
possible to assess the usefulness of the press for a better perception of energy issues and involvement in the necessary measures and their link to SDG 7.

In order to test the hypotheses put forward, different experimental designs and analytical tools have been developed that will allow us to check whether the results obtained are convergent with our initial conjectures. Figure 1 shows a scheme of the methodology steps followed in this research.

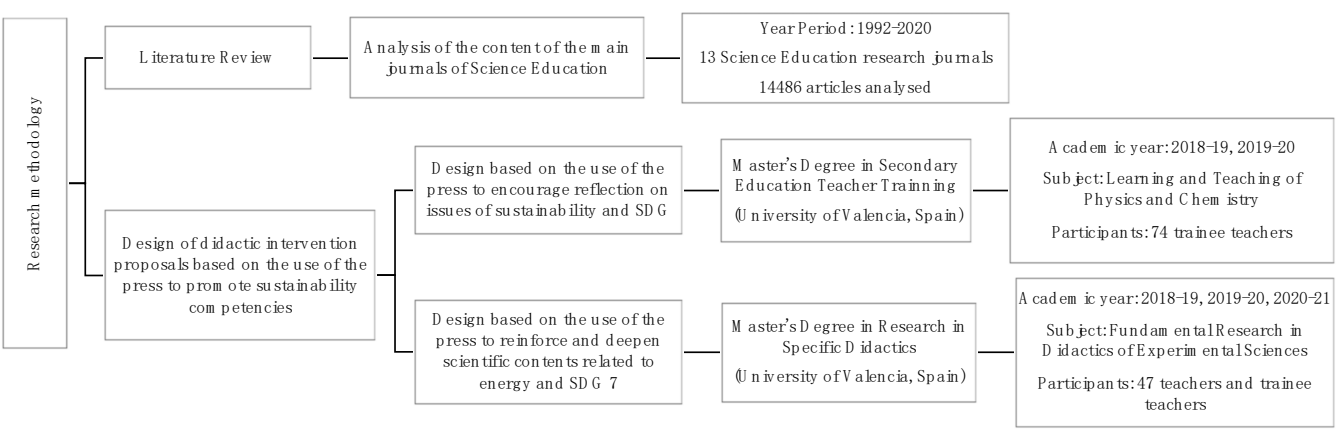

Figure 1. Scheme of the methodology steps in our research. Source: Designed by the authors.

We will now describe the first design to analyse the presence of the use of the press as an educational resource in science education research journals.

\subsection{Attention Paid by Research in Science Education to the Use of the Press as an Instrument of Citizenship Education}

To test the first hypothesis, the content of some of the main journals in the field of science education was analysed in order to find articles on the use of the press in the field of science education. In carrying out this study, previous work by the research team was taken as a reference [80,81]. These investigations covered a study of the literature from 1992, the date of the first Earth Summit held in Rio de Janeiro, to 2005, analysing the contents of some of the main science education journals and identifying articles that explicitly refer to the use of the press. The criteria adopted for the content analysis were as follows:

- A set of journals were selected according to their worldwide dissemination, age and importance, which were considered among the most representative of research in science education;

- Articles from the field of science education research from 1992 to 2020 were read and analyzed.

The following table (Table 2) shows the list of journals analysed:

Table 2. Science education research journals analysed.

\begin{tabular}{c}
\hline Journal (Starting Date of Publication, Country of Origin) \\
Alambique (1994, Spain) \\
Aster (1985, France) ${ }^{1}$ \\
Didáctica de las Ciencias Experimentales y Sociales (1989, Spain) \\
Enseñanza de las Ciencias (1983, Spain) \\
International Journal of Science Education (1979, UK) \\
Investigación en la Escuela (1987, Spain) \\
Journal of Research in Science Teaching (1963, USA) \\
Research in Science Education (1971, Australia) \\
School Science Review (1919, UK) \\
Science \& Education (1992, New Zealand) \\
Science Education (1916, USA) \\
Studies in Science Education (1974, UK) \\
Revista Eureka sobre Enseñanza y Divulgación de las Ciencias (2004, Spain)
\end{tabular}

${ }_{1}^{1}$ Associated with Didaskalia in 2010, originating the new journal RDST-Recherches en Didactique des Sciences et des Technologies. 
We go on to describe a second design which analyses the role that press articles can play in contributing to reflection and debate on issues of sustainability and the SDGs, with the subsequent assessment of the participants, while at the same time allowing for an in-depth study of the relationship between science, technology, society and the environment (STSE).

\subsection{Press Articles to Encourage Reflection and Debate on Socio-Environmental Issues and SDGs} with Trainee Teachers

The design is based on the use of the press as an educational tool with trainee teachers. In particular, we will analyse the results obtained with the use of the press carried out with 74 future teachers attending a Master's degree program in secondary education teacher training, specialising in physics and chemistry, during the 18-19 and 19-20 academic years. The aim of the intervention was to select, use and discuss current news items to reinforce knowledge and deepen the contents of the module on education for sustainability and the SDGs. The sample consists of 2 groups of 39 and 35 students of the subject Learning and Teaching of Physics and Chemistry in the module "Axiological Aspects (Scientific Literacy CA, Education for Sustainability ESD, Classroom Climate and Non-formal Education)".

For each class session, structured in small collaborative groups and with a constructivistoriented methodology, the future teachers must select current news items from the press related to the topics being addressed around scientific literacy and education for sustainability. The news items should be used to encourage reflection and debate on these topics and, at the same time, contribute to a better understanding of the characteristics of scientific activity. At the beginning of each session, 30 minutes (of a 3-hour class) are dedicated to presenting the selected news items, indicating why they were chosen, their importance and their link to the topic being taught. This search and treatment of news should also be useful to link the subject matter studied in class with the STSE relations and to deepen the knowledge of the nature of science [82,83]. Figure 2 shows the steps of that didactic intervention proposal.

Step 1:

Aproach to issues

lated to Scien tific Literacy and ESD
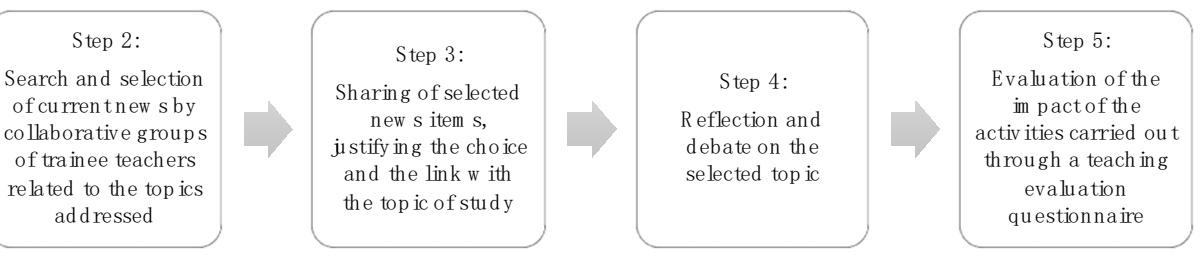

Figure 2. Summary of the intervention proposal performed in the subject of learning and teaching of physics and chemistry of the Master's Degree program in Secondary Education Teacher Training of the University of Valencia (Spain) (18-19 and 19-20 academic years). Source: designed by the authors.

This design is completed with an anonymous questionnaire (see Figure 3) to evaluate the work carried out, with the aim, once the module has finished, of indirectly analysing the participants' assessment of the use of the press during the course and whether it has contributed to the knowledge of SDG 7 and its treatment in the science classroom. In this way, in addition to having an assessment of the aspects of the module that have most interested them, and thus being able to improve or reorient it for the next year, the aim is to determine to what extent the use of the press in the classroom stands out among the aspects that have seemed to them to be of interest.

In this design, the data collection process is carried out through the compilation of the press releases selected by the different collaborative work groups and through the recording of the answers given by the trainee teachers to a teaching evaluation questionnaire (Figure 3). This is an evaluation questionnaire that is frequently used in the research carried out by our group and which has been validated by experts in science education. 


\section{TEACHING ASSESSMENT}

In order to improve this part of the Master's course, please answer the following questions:

- What you think has worked well

- What you think should be improved

- What you missed

Indicate whether the volume of work carried out seemed to you to have been:

Too little, little, adequate, more than desirable, excessive

Figure 3. Questionnaire for assessing the module of the Master's Degree in Secondary Education Teacher Training.

The following design aims to test the usefulness of the press to reinforce and deepen the study of scientific contents, such as those related to energy and its link with SDG 7 and, more generally, with the science of sustainability.

\subsection{Using the Press for the Study of SDG 7 and Sustainability Science}

Another design to show that appropriate use of the press contributes to scientific culture and attention to the SDGs is its ability to deepen the study of certain content.

In this case, we analyse an example of how the press can help to understand and reinforce the contents surrounding a scientific development, such as the science of sustainability, in particular by using an opinion article related to SDG 7, through the analysis of a text that has been written by two scientists.

The design was carried out during the academic years 18-19, 19-20 and 20-21, with 47 teachers and future teachers attending the Master's Degree program in Research in Specific Didactics of the University of Valencia within the subject Fundamental Research in Didactics of Experimental Sciences, in the module entitled "Contributions of Science Education to Sustainability Science". The sample is made up of active and trainee teachers of Primary Education and of science subjects in Secondary Education (11 participants from the 18-19, 19 from the 19-20 and 17 from the 20-21).

Once the module dedicated to the science of sustainability has been addressed, and its characteristics have been studied, it is proposed that the participants analyse, in the light of these characteristics, individually and in detail, the article published in the newspaper El País on 24 July 2014, closely linked to SDG 7, entitled "El fracking o la sordera hacia la ciencia" ("Fracking or the deafness to science"), written by two experts in fracking technology, a geologist and a mining engineer.

The aim of this analysis is to go deeper into the energy problems and the characteristics of the science of sustainability and, in particular, the text helps to understand what happens when these characteristics are not taken into account.

Once the news item has been analysed and discussed by the class as a whole, working in collaborative groups, a search is carried out for other news items in the press related to fracking in order to obtain more points of view and to enrich and support their knowledge of the energy issue in question and its link to the global crisis. Figure 4 shows the steps of this didactic intervention proposal. 


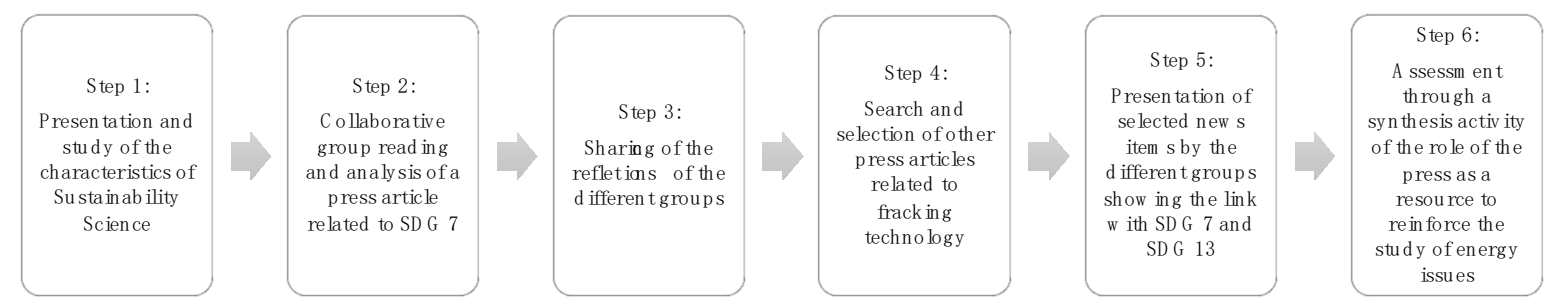

Figure 4. Summary of research steps performed in the subject Fundamental Research in Didactics of Experimental Sciences of the Master's Degree in Research in Specific Didactics of the University of Valencia (Spain) (18-19, 19-20 and 20-21 Academic years). Source: Designed by the authors.

The data collection of this design has been carried out through individual and collective written analysis of the press articles linked to SDG 7.

\section{Results}

3.1. Results on the Presence of the Use of the Press as an Educational Resource in Science Education Research Journals

The following table (Table 3) shows the number of articles analysed in each of the journals listed in Table 2.

Table 3. Number of articles analysed from science education research journals (1992-2020).

\begin{tabular}{cc}
\hline Journal (Starting Date of Publication, Country of Origin) & Number of Articles \\
\hline Alambique (1994, Spain) & 1264 \\
Aster (1985, France) ${ }^{1}$ & 541 \\
Didáctica de las Ciencias Experimentales y Sociales (1989, Spain) & 311 \\
Enseñanza de las Ciencias (1983, Spain) & 955 \\
International Journal of Science Education (1979, UK) & 2460 \\
Investigación en la Escuela (1987, Spain) & 693 \\
Journal of Research in Science Teaching (1963, USA) & 1667 \\
Research in Science Education (1971, Australia) & 1368 \\
School Science Review (1919, UK) & 1660 \\
Science \& Education (1992, New Zealand) & 1410 \\
Science Education (1916, USA) & 1278 \\
Studies in Science Education (1974, UK) & 252 \\
Revista Eureka sobre Enseñanza y Divulgación de las Ciencias & 627 \\
(2004, Spain) & $\mathbf{1 4 , 4 8 6}$
\end{tabular}

${ }^{1}$ Associated with Didaskalia in 2010, originating the new journal RDST—Recherches en Didactique des Sciences et des Technologies.

Tables S1 to S12 of the Supplementary Material reflect the articles found in each of the journals analysed. As can be seen, of the 14,486 articles analysed, only 50 were found that refer explicitly to the use of the press. This represents $0.35 \%$ of all the articles reviewed, so we can conclude that these results support the initial hypothesis of our work. It is clear that research attention in the field of science education to the use of the press is scarce.

Figure 5 shows the number of articles published in each journal that refer to the use of the press in science education, and Figure 6 shows a five-yearly distribution of published papers. 


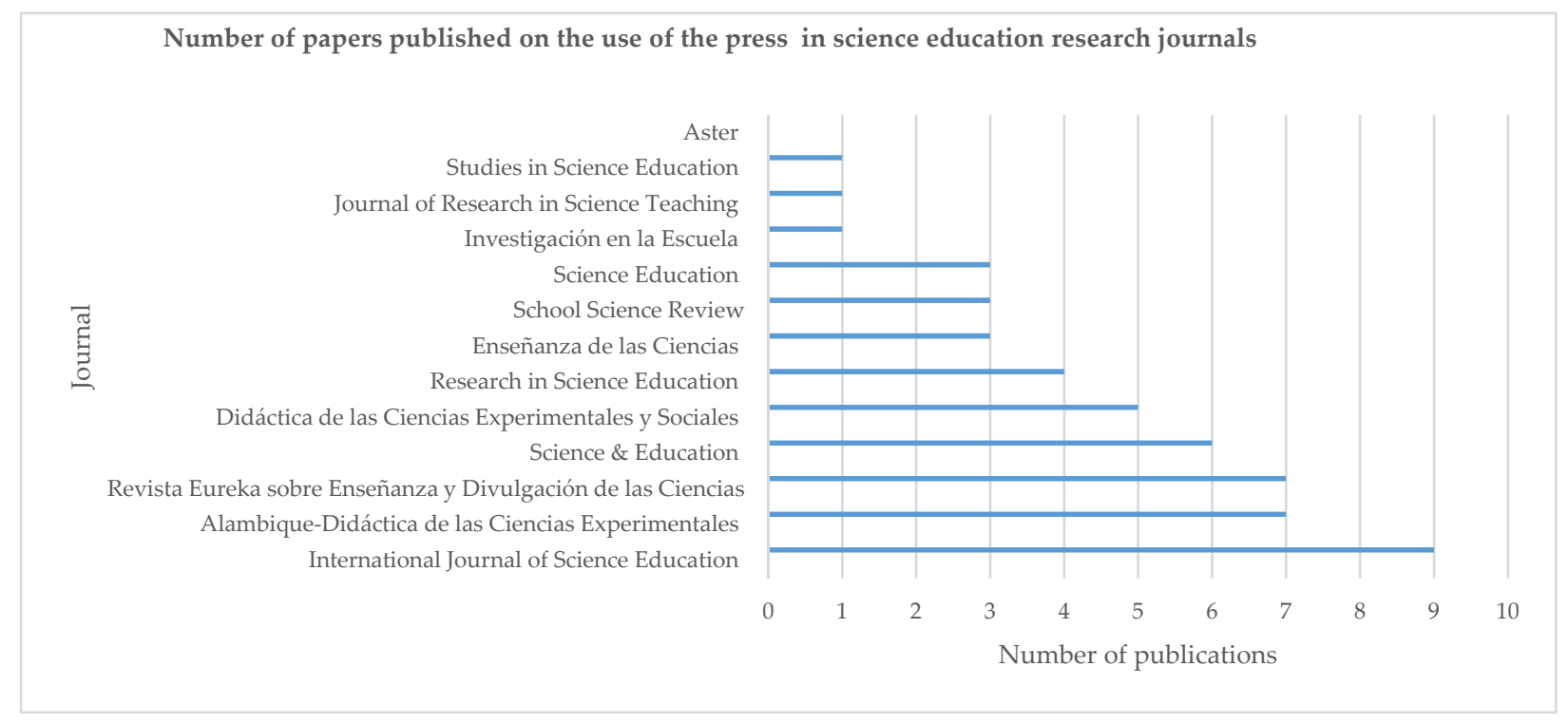

Figure 5. Number of papers published on the use of the press in science education research journals (1992-2020).

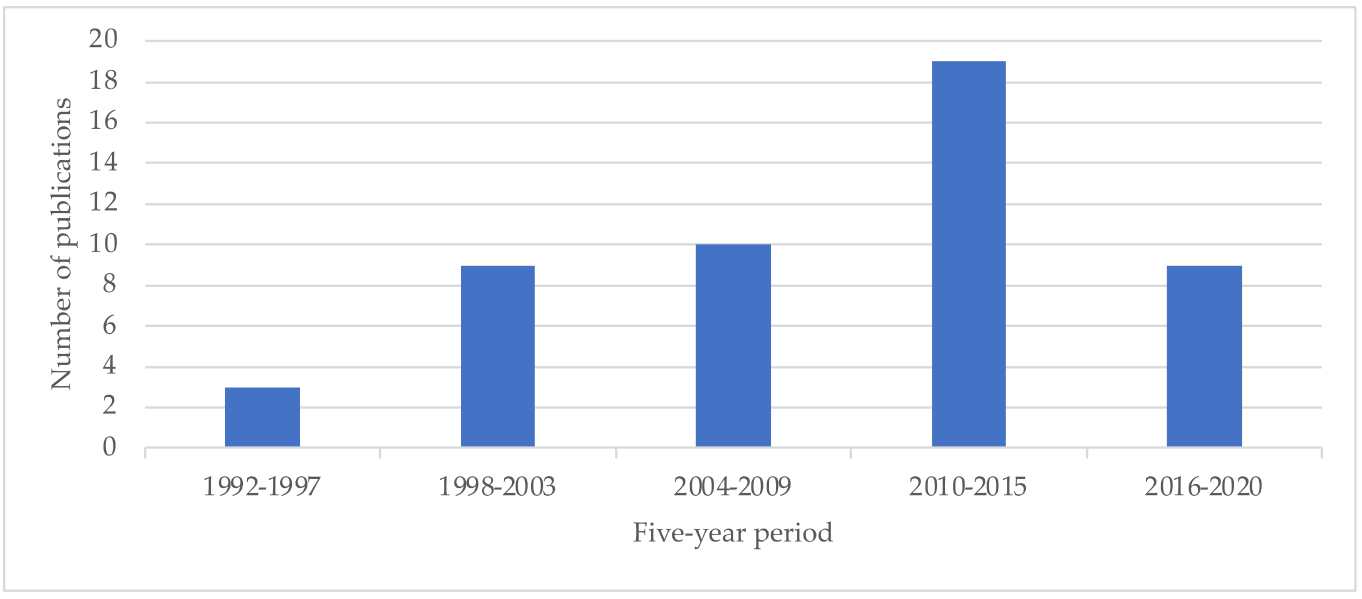

Figure 6. Five-yearly distribution of published papers on the use of the press in science education research journals (1992-2020).

The results obtained by applying the designs to test the usefulness of the press as a tool for imbuing the culture of sustainability in science teacher training and, in particular, to address aspects related to energy and SDG 7 are shown below.

\subsection{Findings on the Use of the Press to Promote Reflection and Debate and Assessment of the Proposal}

As indicated above, during the 18-19 and 19-20 academic years, from the beginning of October to the end of December, the classes of the UVEG's Master's Degree in Secondary Education Teacher Training used press reports to deepen the content on the ESD, the SDGs or the STSE relations corresponding to the syllabus.

The Master's sessions coincided with the celebration of the COP24 Climate Summit in the first year and the COP25 (Madrid) in the second year, which enabled some of the students to select news related to the use of energy, climate change and other aspects related to SDG 7. These current news items contributed to the reflection on these issues and the possibility of discussing them, their possible causes, measures, the role of the summits, etc.

On all occasions, the analysis of the news item led to a fruitful debate and allowed for a deeper understanding of the issues addressed in class, particularly in relation to 
SDG 7. It should be noted that the eight different class teams were asked to look for news items related to the topics being studied, without specifying anything else, in order to see which ones caught their attention and the importance given to energy issues and ESD. With regards to the analysis of the data in this experimental design, the selected news items are classified by categories, as shown in Table 4 , which are linked to the topics that were debated and discussed in class.

Table 4. Analysis network for the classification of the news selected by the collaborative workgroups of trainee teachers.

\begin{tabular}{l|c|c|c|c|c}
\hline \multirow{2}{*}{ News Item } & \multicolumn{5}{|c}{ Category } \\
\cline { 2 - 6 } & Climate Change & COP 24/COP 25 & SDG & Sustainability & Others \\
\hline & & & & & \\
\hline
\end{tabular}

During the first year, of the 36 news items that were proposed in the sessions, 33 were related to ESD. Among the selected news items, 23 were linked to energy and related issues, which shows the interest in the subject, as well as the motivating capacity of the press in connecting the contents of the module with current affairs. Among these news items, it is worth noting that 8 were focused on the Climate Summit (COP24) and that some of the news items mentioned the SDGs. As can be seen in Figure 1, the most frequently chosen sections of the newspaper during the academic year 18-19 were science with 14 news items $(38.9 \%)$, followed by the Spain or Spanish provinces section with 7 news items (19.4\%) and 4 from the society section $(11.1 \%)$, while only 2 news items belonged to the technology section $(5.6 \%)$ and 1 to the world/international section $(2.7 \%)$.

During the second year, of the 24 news items raised in the sessions, 3 dealt with an aspect related to climate change or the global emergency situation; 11 were related to the topic of sustainability in general, of which 7 were related to the SDGs. Thus, the results show the same trends as in the previous year with regards to the interest of the participants in the debate and reflection on the issue of sustainability and the SDGs. It can be observed that, in this academic year, there is a greater selection of news items related to the SDGs, which may indicate an increase in attention (see Figure 7). Among these news items, it is worth highlighting one that mentions the Paris Agreement. This again shows the importance of using the press to deepen the study of socio-environmental issues and to link the contents of the module with current affairs. On this occasion, most of the news items corresponded to the society section with 7 news items out of $24(29.2 \%)$, and only 2 were linked to the science section $(8.3 \%)$, while again the second most chosen section was Spain or Spanish provinces with 4 news items (16.6\%); for more details, see Figure 1.

The results show that the use of the press has made it possible to deepen the content covered in class on ESD and the SDGs, while promoting reflective and respectful attitudes towards divergent opinions on the topics covered in these articles.

At the end of the module, future secondary school physics and chemistry teachers were given a questionnaire to evaluate their work. This questionnaire, which, as will be recalled, makes no direct mention of the press or the activities carried out on it, was answered by 34 Master's students.

The participants value the work done with the press very positively, since $65 \%$ of them in the section "what you think has worked well" refer to the use of the news as a resource of interest, indicating that it has been relevant for them and can also be relevant in their future work with secondary school students. Some examples of their responses are as follows: "The weekly search for news, as well as the debate of the news during the sessions seemed to me a very dynamic way of keeping up to date with the scientific world"; "I really liked the work on the news as I found it a very interesting way of relating the topics to current affairs"; "I really liked the dynamics of the classes, despite being a 3-hour class, it didn't take long. I thought it was a good idea to start the class with a reflection on a piece of news as it is interesting for us to become literate and think critically, at the same time as getting to know the opinion of your classmates." 


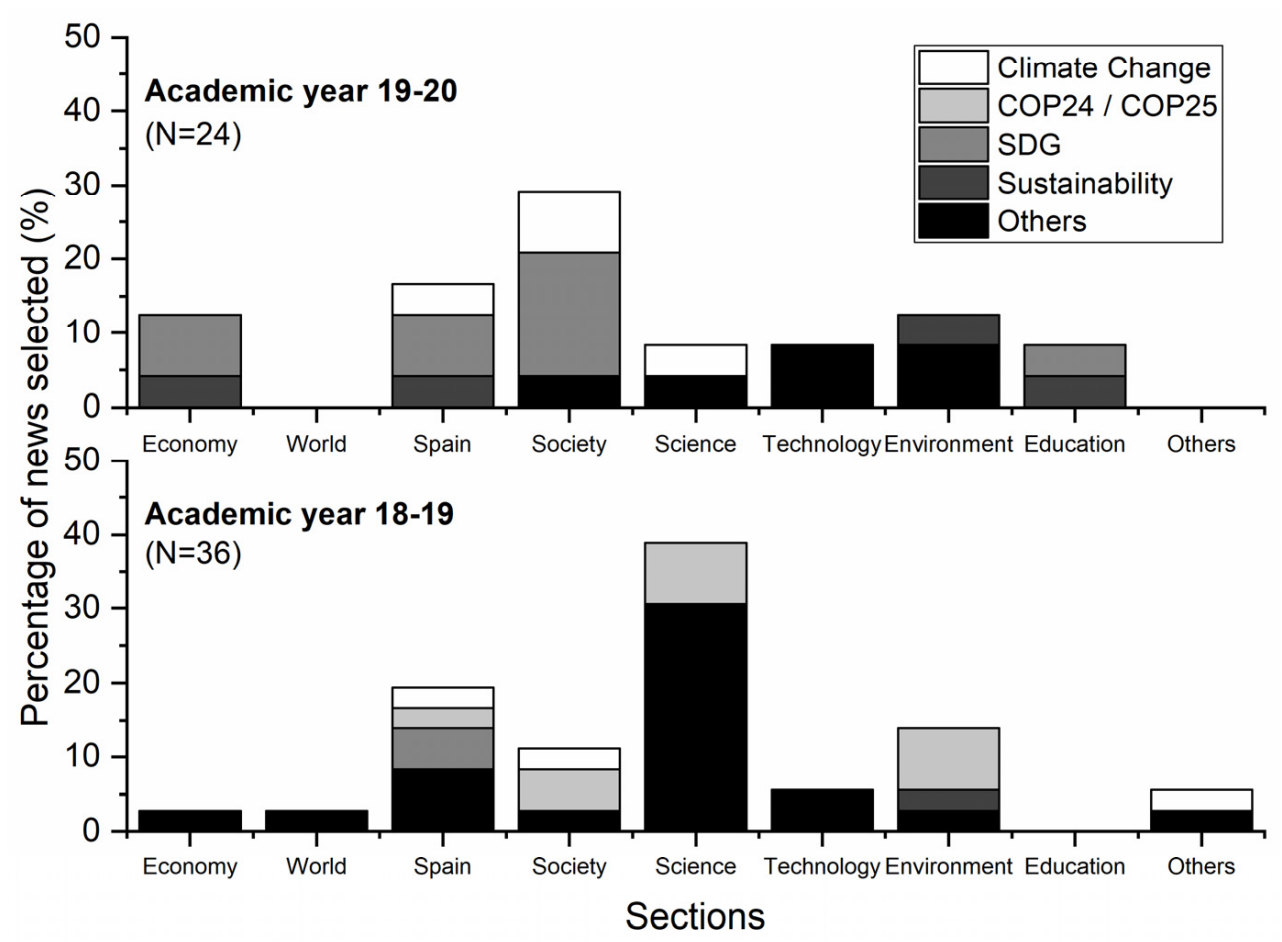

Figure 7. Percentage according to the sections of the newspaper of news chosen by those attending the Master's Degree in Secondary Education Teacher Training during the 18-19 and 19-20 academic years.

\subsection{Results Obtained with the Use of the Press for the Study of SDG 7 in the Perspective of Sustainability Science}

As we have pointed out, we propose the use of a press article to reinforce the study of the energy problem from the perspective of the Science of Sustainability in the Master's Degree in Research in Specific Didactics (MUIDE) in the module dedicated to the contributions of science education to the science of sustainability within the specialisation in experimental sciences. This article is used after studying, in previous sessions, the characteristics of this science that analyses the interrelationships between human societies and natural systems. As already indicated, participants are asked to analyse the content of the article "Fracking or the deafness to science" taking into account the characteristics of the science of sustainability they have just studied, i.e., an inter- and transdisciplinary science that uses holistic strategies, both in time and space.

The results of the implementation of this sequence of activities, related to the use of the press, show that the very careful reading of the article, its subsequent analysis, as well as the debate to which it gives rise with the different interventions and rereadings of the text and other opinions about fracking, constitute as a whole a rich tool for tackling the energy problem. At the same time, they allow for a deeper understanding of the meaning of sustainability science and its characteristics, which visualise the need to overcome the dangers of so-called "expert" visions that are, in fact, reductionist, as they do not take into consideration closely related aspects. In short, the use of the press has allowed the appropriation of the knowledge addressed in the subject. The last academic year in which this design was applied (2020-2021) coincided with the time of the pandemic, which was very useful to deepen our understanding of the causes and their link with the global crisis we are facing.

As stated in Section 2.3 above, the data collection of this design was carried out through individual and collective written analysis of the press article linked to SDG 7. For the analysis of these data, different items related to the effectiveness of the press as an educational resource were established using the network for data collection shown in Table 5. 
Table 5. Network for data collection of the design based on the use of the press for the study of SDG 7 in the perspective of Sustainability Science.

\begin{tabular}{l|l|l|l|l|l}
\hline \multirow{2}{*}{ Participant } & \multicolumn{5}{|c}{ Uses of the Press As an Educational Resource in Science Education } \\
\cline { 2 - 5 } & & & & & \\
\hline & & & & & \\
\hline
\end{tabular}

Among the results of the development of the activity, as reflected in the written analyses of the 47 participants, those involved made it clear that the press can be a very effective tool to:

1. Deepen and improve the learning of the contents dealt with in relation to energy, as well as the repercussions associated with its production and use;

2. Learn about examples in the press of STSE interactions, of the social influence on scientific and technological development, and vice versa;

3. Know which problems arouse the interest of the scientific community and/or society;

4. Study the treatment given to socially controversial issues related to science (as in the case of fracking) and use them as elements of debate in order to develop informed critical attitudes;

5. Value respect for divergent opinions to attain a better understanding of the meaning and importance of SDG 7 and its link with the rest of the universal SDGs.

It is relevant to note how the discussion of the news is an essential factor in helping to understand the need to promote SDG 7 and 13 and to bear in mind the characteristics of sustainability science in order to move towards more sustainable societies.

It is important to point out that all those involved, through the detailed analysis of the article, adequately reflect on the characteristics of sustainability science, particularly its interdisciplinary, transdisciplinary and holistic nature, delving into the need for a global vision and a new energy culture based on savings and renewable sources.

By way of example of the role that the press can play in helping to deepen the issues addressed, the following are some fragments of the responses obtained after reading the press article published on fracking: "There is a lack of a more global vision and long term measures"; "They do not comment on the risks posed by this type of extraction in the long term"; "Critically, I believe that the authors of the text have interests outside of what they show in the text. From what I know about fracking I believe it does cause a great environmental impact on the ecosystems in which it is carried out.... I think this article lacks objectivity and really objective scientific studies"; "The general feeling is that it is not global, it is not considered in the long term"; "fracking may have some advantages, but not related to sustainability and the care and protection of the environment, which it puts at risk at various levels"; "the article tries to outline ideas close to the principles of sustainability science but only to convince about the practice of fracking"; "at no point is there any mention of the importance and involvement of citizens"; "there is no reference to the global connection of local effects"; "the article does not address the characteristics that promote sustainability".

In the ensuing debate, students were aware that this technique ultimately aims to continue extracting (in an expensive and highly polluting way) fossil fuels that contribute to climate change and, therefore, to the degradation of the planet; that technologies are already available to obtain clean and renewable energies in an efficient manner, which must be invested in to promote their generalisation; and that it is essential, in short, to have a holistic view of the problem, also considering the medium and long term repercussions, to which the SDGs contribute by linking the different socio-environmental issues to which we must respond.

For this reason, the idea of interdisciplinarity was highlighted in the debate due to the close links between the problems addressed and, in particular, the need for transdisciplinarity, i.e., the importance of incorporating into the research the points of view of people from 
outside the academic sphere, whose knowledge and capacity for intervention are essential for implementing the measures needed to advance the transition to sustainability.

\section{Discussion}

The results obtained show little attention to the use of the press as a literacy tool in science education, converging with the first hypothesis. It is striking that of the more than 14,000 articles analysed, only $0.35 \%$ of them make explicit reference to the use of the press in science classes.

However, on the whole, we can point out that the implementation of intervention proposals such as those indicated above has had very positive results. It is clear that using the press as an educational tool with science teachers and future science teachers favours their involvement in the achievement and progress of the SDGs. Regarding the validity of the analysis, it is relevant to point out that in our research, we have tried to test the second hypothesis through a "multiple-approach design," which translates into an in-depth study, whose validity is shown in the coherence of the results obtained with the different treatments that have been described throughout the article. These results, in turn, are consistent with those obtained in previous studies by our research group on the use of the press in science education [26,57,80,81].

The main conclusion underlying this study is that the designs worked on in the classroom have made it possible, through reflection, not only to help participants understand and promote the SDGs and SDG 7 in particular, but also:

(i) To raise a critical eye towards the press coverage of scientific and technical issues, in particular, Sustainable Development Goal 7; and

(ii) Experience for themselves the possibilities offered by the use of the press in the classroom to promote scientific literacy and ESD, which is necessary to form an active and empowered citizenry in the face of energy issues and their consequences.

It is important to highlight, in convergence with the second hypothesis, that using the press in the classroom to work with teachers on energy issues has contributed to overcoming decontextualised views of science and technology by linking them to the problems and challenges facing our society. In this way, the aim has been to contribute from science education to ESD and sustainability science, taking into account its interdisciplinarity, transdisciplinarity, global planning and the need for a broad time perspective.

In view of the above, it can be inferred that this framework for research and innovation in the science classroom on energy and sustainability issues through the use of the press in teacher training can represent a relevant instrument both for the education of responsible citizenship and for contributing to knowledge and involvement in the achievement of the SDGs, and specifically SDG 7.

Supplementary Materials: The following are available online at https://www.mdpi.com/article/10 .3390 / su14020857/s1, Table S1: Articles on the use of the press in the journal Alambique-Didáctica de las Ciencias Experimentales (July 1994-June 2020) ( $\mathrm{N}=1264)$, Table S2: Articles on the use of the press in the journal Didáctica de las Ciencias Experimentales y Sociales (1992-2020) $(\mathrm{N}=311)$, Table S3: Articles on the use of the press in the journal Enseñanza de las Ciencias (January 1992-May 2020) $(\mathrm{N}=955)$, Table S4: Articles on the use of the press in the journal International Journal of Science Education (January 1992-March 2020) ( $=2460)$, Table S5: Articles on the use of the press in the journal Investigación en la Escuela (1993-2020) $(\mathrm{N}=693)$, Table S6: Articles on the use of the press in the journal Journal of Research in Science Teaching (January 1992-May 2020) ( $=1667$ ), Table S7: Articles on the use of the press in the journal Research in Science Education (July 1992-May 2020) $(\mathrm{N}=1368)$, Table S8: Articles on the use of the press in the journal School Science Review (March 1992-May 2020) ( $\mathrm{N}=1660)$, Table S9: Articles on the use of the press in the journal Science \& Education (January 1992-April 2020) $(\mathrm{N}=1410)$, Table S10: Articles on the use of the press in the journal Science Education (January 1992-May 2020) ( $=1278)$, Table S11: Articles on the use of the press in the journal Studies in Science Education (1992-March 2020) ( $\mathrm{N}=252)$, Table S12: Articles on the use of the press in the journal Revista Eureka sobre Enseñanza y Divulgación de las Ciencias (January 2004-April 2020) ( $\mathrm{N}=627)$. 
Author Contributions: All authors conceived the experiment, contributed to the analysis of the results and wrote the main parts of the manuscript. All authors have read and agreed to the published version of the manuscript.

Funding: This work has received funding from the European Union's Horizon 2020 research and innovation programme under the grant agreement Marie Sklodowska-Curie No 704998 (RCJ).

Institutional Review Board Statement: We exclude this statement. This study did not require ethical approval.

Informed Consent Statement: Informed consent was obtained from all subjects involved in the study.

Data Availability Statement: We exclude this statement. This study did not report any data.

Conflicts of Interest: The authors declare no conflict of interest. The funders had no role in the design of the study; in the collection, analyses, or interpretation of data; in the writing of the manuscript, or in the decision to publish the results.

\section{References}

1. Bybee, R. Planet Earth in Crisis: How Should Science Educators Respond? Am. Biol. Teach. 1991, 53, 146-153. [CrossRef]

2. Worldwatch Institute. The State of the World; W.W. Norton: New York, NY, USA, 1992; pp. 1984-2017.

3. Comisión Mundial del Medio Ambiente y del Desarrollo. Nuestro Futuro Común; Alianza: Madrid, Spain, 1988.

4. Naciones Unidas. Conferencia de Naciones Unidas sobre el Medio Ambiente y Desarrollo Sostenible. In Programa de Acción Para el Desarrollo Sostenible; Naciones Unidas: New York, NY, USA, 1992; Available online: https:/ / documents-dds-ny.un.org/doc/ UNDOC/GEN/N92/836/58/PDF/N9283658.pdf?OpenElement (accessed on 10 December 2021).

5. $\quad$ Lewin, R. La Sexta Extinción; Tusquets Editores: Barcelona, Spain, 1997.

6. Vilches, A.; Gil-Pérez, D. Una situación de emergencia planetaria a la que debemos y podemos hacer frente. Rev. De Educ. 2009, $N^{o}$ Extra 1, 101-122.

7. Vilches, A.; Macías, O.; Gil-Pérez, D. La Transición a la Sostenibilidad. Un Desafío Urgente Para la Ciencia, la Educación y la Acción Ciudadana. In Temas Clave de Reflexión y Acción; OEI: Madrid, Spain, 2014; ISBN 978-84-7666-204-5.

8. Hicks, D.; Holden, C. Exploring the future: A missing dimension in environmental education. Environ. Educ. Res. 1995, 1, 185-193. [CrossRef]

9. UNESCO. Education 2030. Incheon Declaration and Framework for action for implementation of SDG 4; UNESCO: Paris, France, 2015.

10. UNESCO. Education for Sustainable Development Goals. Learning Objectives; UNESCO: Paris, France, 2017.

11. Hodson, D. Time for action: Science education for an alternative future. Int. J. Sci. Educ. 2003, 25, 645-670. [CrossRef]

12. Solbes, J.; Vilches, A. Papel de las Interacciones Ciencia, Tecnología, Sociedad y Ambiente en la formación ciudadana. Enseñanza De Las Cienc. 2004, 22, 337-347.

13. Vilches, A.; Gil-Pérez, D.; Toscano, J.C.; Macías, O. Obstáculos que pueden estar impidiendo la implicación de la ciudadanía y, en particular, de los educadores, en la construcción de un futuro sostenible. Formas de superarlos. CTS Rev. Iberoam. De Cienc. Tecnol. Y Soc. 2008, 11, 139-172.

14. Aznar, P.; Ull, M.A.; Piñero, A.; Martínez-Agut, M.P. Competencies for sustainability in the curricula of all new degrees from the University of Valencia (Spain). In Handbook of Higher Education for Sustainable Development; Barth, M., Michelsen, G., Rieckmann, M., Thomas, I., Eds.; Routledge Publishers: London, UK, 2015; pp. 434-444.

15. UNESCO. Decade of Education for Sustainable Development 2005-2014 International Implementation Scheme; UNESCO: Paris, France, 2005; Available online: http:/ / unesdoc.unesco.org/images/0014/001486/148654e.pdf (accessed on 10 December 2021).

16. Gil-Pérez, D.; Vilches, A.; Toscano, J.C.; Macías, O. Década de la educación para un futuro sostenible (2005-2014): Un punto de inflexión necesario en la atención a la situación del mundo. Rev. Iberoam. De Educ. 2006, 40, 125-178.

17. Naciones Unidas. Transformar Nuestro Mundo: La Agenda 2030 Para el Desarrollo Sostenible; Naciones Unidas: New York, NY, USA, 2015; Available online: https://unctad.org/meetings/es/SessionalDocuments/ares70d1_es.pdf (accessed on 10 December 2021).

18. Tollefson, J. Global industrial carbon emissions to reach all-time high in 2018. Nature 2018, 3, 370. [CrossRef]

19. UNESCO. Shaping the Future We Want. Decade of Education for Sustainable Development (2005-2014) Final Report; UNESCO: Paris, France, 2014; Available online: http:/ / unesdoc.unesco.org/images/0023/002303/230302e.pdf (accessed on 10 December 2021).

20. Cebrián, G.; Junyent, M. Competencies in Education for Sustainable Development: Exploring the Student Teachers' Views. Sustainability 2015, 7, 2768-2786. [CrossRef]

21. Aznar, P.; Calero, M.; Martínez-Agut, M.P.; Mayoral, O.; Ull, À.; Vázquez-Verdera, V.; Vilches, A. Training Secondary Education Teachers through the Prism of Sustainability: The Case of the Universitat de València. Sustainability 2018, 10, 4170. [CrossRef]

22. Risco, M.; Cebrián, G. Análisis de la percepción de la educación para la sostenibilidad por parte del profesorado de Educación Secundaria y Bachillerato. Enseñanza De Las Cienc. 2018, 36, 141-162.

23. Calero, M.; Mayoral, O.; Ull, A.; Vilches, A. La educación para la sostenibilidad en la formación del profesorado de ciencias experimentales en Secundari. Enseñanza De Las Cienc. 2019, 37, 157-175. 
24. Kates, R.W.; Clark, W.C.; Corell, R.; Hall, J.M.; Jaeger, C.C.; Lowe, I.; McCarthy, J.J.; Schellnhuber, H.J.; Bolin, B.; Dickson, N.M.; et al. Sustainability Science. Science 2001, 292, 641-642. [CrossRef] [PubMed]

25. Komiyama, H.; Takeuchi, K. Sustainability science: Building a new discipline. Sustain. Sci. 2006, 1, 1-6. [CrossRef]

26. Calero, M.; Vilches, A.; Gil-Pérez, D. Necesidad de la transición a la sostenibilidad: Papel de los medios de comunicación en la formación ciudadana. Didáctica De Las Cienc. Exp. Y Soc. 2013, 27, 235-254. [CrossRef]

27. Vilches, A.; Gil-Pérez, D. Ciencia de la Sostenibilidad: ¿Una nueva disciplina o un nuevo enfoque para todas las disciplinas? Rev. Iberoam. De Educ. (RIE) 2015, 69, 39-60. [CrossRef]

28. Rennie, L.J.; Feher, E.; Dierking, L.D.; Falk, J.H. Toward an agenda for advancing research on science learning in out-of-school settings. J. Res. Sci. Teach. 2003, 40, 112-120. [CrossRef]

29. Tal, T. Out-of-School: Learning Experiences, Teaching and Students' Learning. In Second International Handbook of Science Education; Fraser, B.J., Tobin, K., McRobbie, C.J., Eds.; Springer: Dordrecht, The Netherlands, 2012; pp. 1109-1122.

30. Fraser, B.J.; Tobin, K.; McRobbie, C.J. Second International Handbook of Science Education; Springer: Dordrecht, The Netherlands, 2012; Chapters 70-78.

31. Scrive, M. Le film d'exposition scientifique, un choc entre deux cultures. Aster 1989, 9, 69-83. [CrossRef]

32. Pedretti, E.T. Kuhn meets T. Rex: Critical Conversations and New Directions in Science Centers and Science Museums. Stud. Sci. Educ. 2002, 37, 1-42. [CrossRef]

33. Pedretti, E. Perspectives on learning through critical issues-based science center exhibitions. Sci. Educ. 2004, 88 (Suppl. 1), 34-47. [CrossRef]

34. Pedretti, E. Informal Science Education: Critical Conversations and New Directions (Editorial). Can. J. Sci. Math. Technol. Educ. 2006, 6, 1-4. [CrossRef]

35. Dierking, L.D.; Falk, J.H.; Rennie, L.J.; Anderson, D.; Ellenbogen, K. Policy Statement of the "Informal Science Education" Ad Hoc Committee. J. Res. Sci. Teach. 2003, 40, 108-111. [CrossRef]

36. Martin, L. An Emerging Research Framework for Studying Informal Learning and Schools. Sci. Educ. 2004, 88 (Suppl. 1), 71-82. [CrossRef]

37. Abell, S.K.; Lederman, N.G. Handbook of Research on Science Education; Routledge: New York, NY, USA, 2007.

38. Greenberg, M.; Sandman, P.; Sachsan, D.; Salomone, K. Network television news coverage of environmental risks. Environment 1989, 31, 16-44. [CrossRef]

39. Greenberg, M.; Sandman, P.; Sachsan, D.; Salomone, K. Risk, drama and geography in the coverage of environmental risk by network TV. Journal. Q. 1989, 66, 267-276. [CrossRef]

40. Huckle, J. Using television critically in Environmental Education. Environ. Educ. Res. 1995, 1, 291-304. [CrossRef]

41. Robinson, M.; Trojok, T.; Norwisz, J. The ranking of global environmental issues and problems by Polish Secondary students and teachers. Electron. J. Sci. Educ. 1997, 2, 1-16.

42. Riechard, D.E.; Peterson, S.J. Perception of environmental risk related to gender, community, socio-economic setting, age and lcus of control. J. Environ. Educ. 1998, 30, 11-19. [CrossRef]

43. Robinson, M.; Kaleta, P. Global environmental priorities of secondary students in Zarbre, Poland. Int. J. Sci. Educ. 1999, 21, 499-514. [CrossRef]

44. Aguaded, S.; Alanís, L.; Jiménez Pérez, R. Los riesgos ambientales: De lo vivido a la experiencia elaborada en Doñana. Alambique 2000, 25, 45-54.

45. Jarman, R.; Mcclune, B. A survey of the use of newspapers in science instruction by secondary teachers in Nothern Ireland. Int. J. Sci. Educ. 2002, 24, 997-1020. [CrossRef]

46. Jarman, R.; Mcclune, B. Developing scientific literacy. Using News Media in the Classroom; Open University Press: Maidenhead, UK, 2007.

47. De Pro Bueno, A. La enseñanza no formal de las ciencias. Alambique 2005, 43, 5-7.

48. De Pro Bueno, A.; Ezquerra, A. ¿Qué ciencia ve nuestra sociedad? Alambique 2005, 43, 37-48.

49. Nisbet, M.C.; Aufderheide, P. Documentary Film: Towards a Research Agenda on Forms, Functions, and Impacts. Mass Commun. Soc. 2009, 12, 450-456. [CrossRef]

50. Vílchez, J.E. La problemática ambiental en los medios. Propuesta de un protocolo de análisis para su uso como recurso didáctico. Enseñanza De Las Cienc. 2009, 27, 421-432.

51. García-Carmona, A. Naturaleza de la ciencia en noticias científicas de la prensa: Análisis del contenido y potencialidades didácticas. Enseñanza De Las Cienc. 2014, 32, 493-509.

52. Fančovičova, J.; Prokop, P.; Uşak, M. Web-Site as an Educational Tool in Biology Education: A Case of Nutrition Issue. Kuram ve Uygulamada Eğitim Bilimleri. Educ. Sci. Theory Pract. 2010, 10, 907-921.

53. Jarman, R.; Mcclune, B. El Desarrollo del Alfabetismo Científico. El Uso de Los Media en el Aula; Ediciones Morata, S.L.: Madrid, Spain, 2010.

54. Jarman, R.; Mcclune, B. Science Newswise. Educ. Sci. 2011, 245, 27.

55. UNESCO. La educación en Materia de Comunicación; UNESCO: Paris, France, 1984.

56. Obach, X. Cómo ver los programas informativos. Cuad. De Pedagog. 2000, 297, 69-71.

57. Chuliá, R.; Vilches, A. Energía asequible y no contaminante: El ODS 7 en la prensa y su utilización como recurso en la formación del profesorado. Actas electrónicas del XI Congreso Internacional en Investigación en Didáctica de las Ciencias 2021. 
Aportaciones de la Educación Científica Para un Mundo Sostenible; Cañada, F., Reis, P., Eds.; Enseñanza de las Ciencias: Lisboa, Portugal, 2021.

58. Sancho, J.; Vilches, A.; Gil-Pérez, D. Los documentales científicos como instrumentos de educación para la sostenibilidad. Rev. Eureka Sobre Enseñanza Y Divulg. De La Cienc. 2010, 7, 667-681. [CrossRef]

59. Klosterman, M.L.; Sadler, T.D.; Brown, J. Science Teachers' Use of Mass Media to Address Socio-Scientific and Sustainability Issues. Res. Sci. Educ. 2012, 42, 51-74. [CrossRef]

60. Collins, D.E.; Genet, R.M.; Christian, D.G. Crear una nueva narrativa para promover la Sostenibilidad. In The State of the World 2013: Is Sustainability Still Possible? Worldwatch Institute, W.W. Norton: New York, NY, USA, 2013.

61. Ull, M.A.; Piñero, A.; Martínez-Agut, M.P.; Aznar, P. Preconcepciones y actitudes del profesorado de Magisterio ante la incorporación en su docencia de competencias para la Sostenibilidad. Enseñanza De Las Cienc. 2014, 32, 91-112. [CrossRef]

62. Collazo, L.; Geli, A. Avanzar en la educación para la sostenibilidad. Combinación de metodologías para trabajar el pensamiento crítico y autónomo, la reflexión y la capacidad de transformación del sistema. Rev. Iberoam. De Educ. 2017, 73, 131-154.

63. Gil-Pérez, D.; Macedo, B.; Martínez Torregrosa, J.; Sifredo, C.; Valdés, P.; Vilches, A. ¿Cómo Promover el Interés por la Cultura Científica? Una Propuesta Didáctica Fundamentada para la Educación Científica de Jóvenes de 15 a 18 Años; OREALC/UNESCO: Santiago de Chile, Chile, 2005.

64. Macedo, B.; Salgado, S. Educación ambiental y educación para el Desarrollo Sostenible en América Latina. Forum de sostenibilidad Rev. De La Cátedra UNESCO Sobre Desarro. Sosten. 2007, 1, 29-31.

65. Rudolph, J.L. Inquiry, Instrumentality, and the Public Understanding of Science. Sci. Educ. 2005, 89, 803-821. [CrossRef]

66. Lee, O.; Buxton, C.; Lewis, S.; Leroy, K. Science inquiry and Student diversity: Enhanced abilities and continuing difficulties after an instructional intervention. J. Res. Sci. Teach. 2006, 43, 607-656. [CrossRef]

67. CRUE. Directrices para la Introducción de la Sostenibilidad en el Currículum; Actualización de la Declaración Institucional Aprobada en 2005; MEC: Madrid, Spain, 2012; Available online: https://www.ucm.es/data/cont/docs/3-2016-03-02-DIRECTRICES\%20 SOSTENIBILIDAD\%20CRUE\%202012.pdf (accessed on 10 December 2021).

68. Albareda-Tiana, S.; Azcárate Goded, P.; Muñoz-Rodríguez, J.M.; Valderrama-Hernández, R.; Ruiz-Morales, J. Evaluar competencias en sostenibilidad en los grados y pos $\neg$ grados de educación: Propuesta de un instrumento. Enseñanza De Las Cienc. 2019, 37 , 11-29. [CrossRef]

69. Albareda-Tiana, S.; Ruiz-Morales, J.; Azcárate, P.; Valderrama-Hernández, R.; Muñoz, J.M. The EDINSOST Project: Implementing the sustainable development goals at university level. In Universities as Living Labs for Sustainable Development: Supporting the Implementation of the Sustainable Development Goals; Leal Filho, W., Salvia, A.L., Pretorius, R., Brandli, L., Manolas, E., Alves, M.F.P., Azeiteiro, U., Rogers, J., Shiel, C., Paço, A., Eds.; Springer: Berlin, Germany, 2019; pp. 193-210.

70. Cebrián, G.; Pascual, D.; Moraleda, Á. Perception of sustainability competencies amongst Spanish pre-service secondary school teachers. Int. J. Sustain. High. Educ. 2019, 20, 1171-1190. [CrossRef]

71. Rieckmann, M. Future-oriented higher education: Which key competencies should be fostered through university teaching and learning? Futures 2012, 44, 127-135. [CrossRef]

72. Wiek, A.; Withycombe, L.; Redman, C.L. Key competencies in sustainability: A reference framework for academic program development. Sustain. Sci. 2011, 6, 203-218. [CrossRef]

73. United Nations Economic Commission for Europe (UNECE). Strategy for Education for Sustainable Development. Learning for the future: Competences in Education for Sustainable Development; UNECE: Geneva, Switzerland, 2011; Available online: https: //www.unece.org/fileadmin/DAM/env/esd/ESD_Publications/Competences_Publication.pdf (accessed on 10 December 2021).

74. United Nations Economic Commission for Europe (UNECE). Empowering Educators for a Sustainable Future. Tools for Policy and practice Workshops on Competences in Education for Sustainable Development; UNECE: Geneva, Switzerland, 2013.

75. United Nations Economic Commission for Europe (UNECE). Ten Years of the UNECE Strategy for Education for Sustainable Development; UNECE: New Yok, NY, USA; Geneva, Switzerland, 2016.

76. de Haan, G. The development of ESD-related competencies in supportive institutional frameworks. Int. Rev. Educ. 2010, 56, 315-328. [CrossRef]

77. Murga-Menoyo, M.A. Competencias para el desarrollo sostenible: Las capacidades, actitudes y valores meta de la educación en el marco de la Agenda global post-2015. De Educ. 2015, 13, 55-83. [CrossRef]

78. Vila, E.S.; Caride, J.A.; Buxarrais, M.R. Educación, sostenibilidad y ética: Desafíos ante los Objetivos de Desarrollo Sostenible (ODS). In Proceedings of the Educación en la Sociedad de Conocimiento y el Desarrollo Sostenible: XXXVII Seminario Interuniversitario de Teoría de la Educación, La Laguna, Spain, 11 November 2018.

79. Nilsson, M.; Chisholm, E.; Griggs, D.; Howden-Chapman, P.; McCollum, D.; Messerli, P.; Neumann, B.; Stevance, A.-S.; Visbeck, M.; Stafford-Smith, M. Mapping interactions between the sustainable development goals: Lessons learned and ways forward. Sustain. Sci. 2018, 13, 1489-1503. [CrossRef]

80. Gadea, I.; Vilches, A.; Gil-Pérez, D. Posibles usos de la prensa en la educación científica y tecnológica. Didáctica De Las Cienc. Exp. Y Soc. 2009, 23, 153-169.

81. Calero, M.; Vilches, A.; Gil Pérez, D. La atención de la prensa a la situación de emergencia planetaria. Didáctica De Las Cienc. Exp. Y Soc. 2006, 20, 69-88. 
82. Abd-El-Khalick, F.; Lederman, N. Improving Science Teachers' Conceptions of Nature of Science: A Critical Review of the Literature. Int. J. Sci. Educ. 2000, 22, 665-701. [CrossRef]

83. Ferreira-Gauchía, C.; Vilches, A.; Gil-Pérez, D. Concepciones docentes acerca de la naturaleza de la tecnología y de las relaciones Ciencia, Tecnología, Sociedad y Ambiente en la educación tecnológica. Enseñanza De Las Cienc. 2012, 30, $253-272$. 